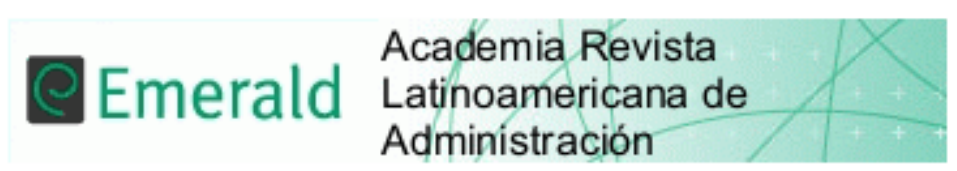

\title{
Cash management and performance of index mutual funds
}

\begin{tabular}{|r|l|}
\hline Journal: & Academia Revista Latinoamericana de Administracion \\
\hline Manuscript ID & ARLA-07-2020-0158 \\
\hline Manuscript Type: & Research Paper \\
\hline Keywords: & cash management, index fund, mutual fund, performance \\
\hline \multicolumn{2}{|l}{} \\
\hline
\end{tabular}

SCHOLARONE ${ }^{\text {m }}$

Manuscripts 


\title{
Cash management and performance of index mutual funds
}

\begin{abstract}
Purpose: This study aims to assess the relationship between cash management and fund performance in index fund portfolios.
\end{abstract}

Design/methodology/approach: Using a sample of 104 index mutual funds that track the Standard and Poor's 500 stock market index from January 1999 to December 2016, the authors employ quintile-portfolios and different regression models to assess the differences in risk-adjusted monthly returns experienced by index funds managing different cash levels in their portfolios. To ensure the robustness of the results, different sub-periods and market states are considered in the analyses, as well as other exogenous factors and fund characteristics affecting the level of portfolio cash holdings and index fund performance.

Findings: Results show that index funds holding higher levels of cash and cash equivalents performed significantly worse than their low-cash counterparts. This evidence remains even after considering different sub-periods and bullish and bearish market conditions, and controlling for fund expenses and other variables that could drive this cash-performance relationship.

Originality/value: This study expands the extant literature analyzing cash management in the mutual fund industry. More specifically, the analyses focus on index fund portfolios that replicate a specific benchmark, given that their performance differences should not be related to the market evolution but to the factors derived from the fund 
management and other exogenous issues. These findings are of interest to managers and investors willing to improve their risk-adjusted returns while investing as diversified as a stock market index.

Keywords: cash management; index fund; mutual fund; performance

Paper type: Research paper

Management area: Business Economics

JEL Code: G11, G17, G23

\section{Resumen}

Objetivo: El objetivo de este estudio es analizar la relación existente entre la gestión de efectivo y el desempeño consiguiente en las carteras de fondos de inversión indexados.

Diseño/metodología/perspectiva: Utilizando una muestra de 104 fondos que replican el índice bursátil Standard and Poor's 500 desde enero de 1999 hasta diciembre de 2016, se emplean carteras hipotéticas que invierten en fondos similares y diferentes análisis de regresión para analizar las diferencias en las rentabilidades ajustadas mensuales entre fondos indexados que gestionan diferentes niveles de efectivo en sus carteras. Por motivos de robustez, se tienen en cuenta diversos subperiodos y estados de mercado, así como otros factores exógenos y características de los fondos que afectan tanto al nivel de efectivo mantenido en la cartera indexada como al desempeño de la misma. 
Resultados: Los resultados muestran que los fondos indexados que gestionan niveles de efectivo más elevados experimentan un desempeño significativamente menor que otros fondos comparables que mantienen menores porcentajes de efectivo en sus carteras de inversión. Se obtiene una evidencia similar tras considerar diferentes subperiodos y momentos alcistas y bajistas de mercado, así como al considerar los gastos propios de cada fondo y otras variables que podrían afectar esta relación entre el rendimiento y el efectivo gestionado.

Originalidad/contribución: Este estudio contribuye a la literatura existente que analiza la gestión de efectivo en la industria de fondos de inversión. Más específicamente, los análisis se centran en carteras de fondos que replican un índice bursátil específico, dado que las diferencias en sus rendimientos en este tipo de fondos no deberían originarse por la evolución del mercado, sino a causa de factores relacionados con la gestión de sus carteras y otros componentes exógenos al índice bursátil. Estos hallazgos son de interés para gestores e inversores que pretendan mejorar sus rentabilidades ajustadas al invertir mediante una estrategia tan diversificada como un índice bursátil.

Palabras clave: gestión de efectivo; fondo indexado; fondo de inversión; desempeño Tipo de artículo: Trabajo de investigación

Management area: Business Economics

JEL Code: G11, G17, G23 


\section{Introduction}

The mutual fund industry has experienced huge growth over the last decades, as illustrated by an increase of more than $50 \%$ in assets under US mutual fund management, from 12 trillion dollars in 2007 to 18.7 trillion in 2017. This striking development has attracted the attention of professionals and academics, who have attempted to understand the behavior of mutual funds over time, as well as their financial results.

In this context, the overall evidence found in the literature is that active funds experience, on average, negative alphas (Gruber, 1996; Berk and Green, 2004; Adams et al., 2016; among others). Moreover, several studies suggest that investors are more likely to achieve higher returns through passive indexing strategies rather than investing in actively-managed portfolios (Malkiel, 2003; Bogle, 2016).

In light of this evidence, interest in index mutual funds began to increase as their assets rose year by year. For instance, index portfolios managed 6.72 trillion dollars in 2017, that is, approximately $35 \%$ of the total net asset under mutual fund management. Index funds are passively-managed investment vehicles aiming to track a benchmark, and holding most of the equities included in that index in similar proportions. Given their low expenses, these funds are offered as an attractive opportunity to investors willing to invest in a portfolio that is as diversified as a stock market index (Aiello and Chieffe, 1999).

Previous studies analyzing index mutual funds have focused on abnormal trading and returns of index funds during index rebalancing (Chen et al., 2006; Green and Jame, 
2011). Other articles have addressed the success of indexing strategies through their efficiency (Baghdadabad et al., 2013) and by measuring the relative outperformance of index funds compared to actively-managed funds (Frino and Gallagher, 2001; Bogle, 2002). In the same vein, other authors have observed the substitutability of index mutual funds and other passive investment vehicles such as exchange-traded funds (Agapova, 2011), concluding that index funds provide investors with higher risk-adjusted returns (Elton et al., 2002; Kostovetsky, 2003; Chang and Krueger, 2010).

These funds, however, also present some limitations (Elebash, 1993), such as the inability to exploit market inefficiencies, the impartial selection of specific stocks to include in their portfolio, or the hidden cost derived from the index premium during the rebalancing of the benchmark portfolio (Petajisto, 2011). Moreover, index funds are not able to fully replicate their benchmark, and their management involves a certain degree of tracking error (Frino and Gallagher, 2002; Strydom et al., 2015). Apart from other exogenous factors like market volatility, this tracking error is affected by several variables related to the fund's management, such as the inherent expenses borne in any portfolio, or the investors' fund flows going into and out of the fund.

In order to reduce the potential adverse effects of these factors, index funds should invest a percentage of their holdings in cash or cash equivalents. In other words, if these funds had enough liquidity in their portfolios to handle investors' outflows and managerial expenses, their managers should neither sell other equities nor incur additional transaction costs that would lead to a detriment in performance. 
Along these lines, the reader should note that cash management in index funds' portfolios may affect their benchmark-adjusted returns, and the analysis of their cash holdings in the index fund management is therefore of interest. Besides managerial expenses, cash management should be one of the few determinants influencing index fund performance. That is, if these funds invested their cash in short-term securities experiencing lower returns than the risk-free asset used in traditional performance methodologies (i.e., the one-month Treasury bill rate), their alphas would worsen due to the increase in the level of cash holdings kept in their portfolios.

Despite this relevance, the effect of holding higher levels of cash on the performance of index fund portfolios remains inconclusive, since most of the literature analyzing cash portfolio holdings focuses on actively-managed funds. Moreover, there is some controversy about the financial benefits of managing a large amount of cash in a portfolio. On the one hand, some studies document a positive relationship between corporate cash holdings and performance in both publicly traded firms (e.g., Opler et al., 1999) and actively-managed mutual funds (Simutin, 2010; 2014). On the other hand, other studies point out that the lower expected returns on cash relative to stocks could deteriorate fund performance on a net return basis (Wermers, 2000; Adams et al., 2009), and that aggregate cash holdings are not associated with greater managerial abilities (Yan, 2006).

Given this gap in the literature, this paper aims to assess the relationship between the level of cash held in the portfolio and the subsequent performance of index mutual funds. Using a sample of domestic index funds that track the most representative US stock market index (i.e., the Standard and Poor's 500 index) during the period from 
January 1999 to December 2016, we show that index mutual funds managing higher levels of cash assets provide investors with worse risk-adjusted returns than their lowcash counterparts. Moreover, this evidence persists over time since investment strategies based on previous low cash positions significantly outperform portfolios investing in index funds with high liquidity levels.

Nonetheless, other factors could potentially drive our results if they affect the level of cash assets held in the index fund portfolio. For that reason, we next analyze the impact of several variables on the portfolio liquidity, such as managerial and operating expenses, investors' flows and market volatility, among others. Our results show that smaller funds, younger funds and funds experiencing higher net flows tend to report higher liquidity positions. Moreover, the level of cash and cash holdings kept in the portfolio seems to persist over time, which may be related to the funds' liquidity policy.

In light of these results, we then examine the impact of the cash holdings management on the fund performance, while controlling for other determinants such as the size of the fund, fund age, managerial and operating expenses, investors' flows, and other external factors. We also use quantile regressions to observe the effect of cash holdings on different levels of the performance distribution. Results show that the cash-performance relationship remains negative, even after considering other potential determinants in the analyses.

In short, this article makes some contributions to the extant literature. Firstly, we examine whether portfolio cash positions affect index fund performance, and document that index funds holding higher levels of cash and cash equivalents provide investors 
with lower overall risk-adjusted returns than low-cash index funds. We also observe that this relationship persists over time since investment fund strategies based on higher previous levels of cash holdings lead to worse overall abnormal returns. Further, we analyze the impact of some factors on the index fund liquidity, and observe that smaller funds, younger funds and funds experiencing greater net cash flows also hold higher levels of cash in their portfolio. In addition, we apply a quantile regression approach to obtain a more comprehensive assessment of the effect of several index fund performance determinants. To our knowledge, this methodology has not been applied in previous studies analyzing the performance of index mutual funds. Our results show that index fund risk-adjusted returns worsen when the level of cash and cash equivalents increases, even after considering managerial and operating costs, investors' flows, fund size and other control variables in the analyses.

The remainder of the paper is organized as follows. Section 2 defines the performance methodology and data employed in this study. Section 3 presents the overall results deriving from the empirical analyses. Finally, section 4 provides some concluding remarks.

\section{Performance methodology and data}

We apply a one-factor model to assess the index fund performance. That is, we compute Jensen's alpha (Jensen, 1968), which is the intercept of the model described in Equation (1).

$$
R_{p, t}=\alpha_{p}+\beta_{p} R_{b, t}+\varepsilon_{p, t}
$$


where $R_{p, t}$ is the return of the index fund $p$ in excess of the risk-free asset during the period $t ; R_{b, t}$ is the excess risk-free return of the primary benchmark of the index fund during the same period; and $\alpha_{p}$ reflects the average abnormal return provided by the index fund $p$ after adjusting for the benchmark returns during that period. The data on the risk-free asset is obtained from the website of Professor Kenneth R. French.

We restrict our study to the funds mimicking the behavior of the Standard \& Poor's 500 index (S\&P500), since it is by far the most representative stock market index in the US fund industry and the one with the largest number of associated index funds.

Data on returns, portfolio holdings and index fund characteristics were obtained from the Morningstar database. We collated information on the fund's reported benchmark, inception date, total net assets (TNA) under fund management, fund flows, net expense ratio, portfolio turnover, holdings on cash and cash equivalents, and daily return index. According to Morningstar, this last item refers to the daily account balance experienced by an investor who purchased one share on the fund's inception date, so it reflects any uninvested cash accrued to the account (such as future distributions and daily dividends). Therefore, the daily returns of each fund during period $t$ are constructed by comparing the data on this item in periods $t$ and $t-1$. Similarly, we also obtained from Morningstar the data to construct daily returns for the Standard \& Poor's Total Returns (S\&P500 TR) index.

Our initial sample comprises 374 US share-class index funds during the period January 1999-December 2016. Grouping all the share classes that belong to the same fund yielded 126 index funds. These funds' prospectuses state that they aim to track the S\&P500 TR 
index. We then filtered the sample by removing all the observations that are susceptible to data errors or that do not report any information about the data we are interested in. Next, we deleted the observations related to funds with less than $\$ 15$ million under management or less than two years since inception. This data-cleaning process is required to ensure robustness to incubation issues or upward-biased reported returns (Evans, 2010; Yan, 2008; among others). In addition, we required the sample funds to report complete data on daily returns for each year in order to obtain maximum accuracy in the results. Our final sample contains 104 S\&P500 index funds. This sample is free of survivorship-bias since we consider all the funds (both surviving and non-surviving funds) in existence during the period under analysis.

\section{(INSERT TABLE I ABOUT HERE)}

Table I reports the main descriptive statistics of the sample. Panel A and Panel B present the mean and the standard deviation for some characteristics of the index fund sample and their benchmark, respectively.

As shown in Panel A, S\&P500 index mutual funds managed a huge amount of assets over the sample period, especially during the latter years. Specifically, these funds held an average of 5.14 billion dollars in their portfolios during the 1999-2016 period, but their assets increased to 6.58 billion dollars per fund after the recent financial crisis. These figures illustrate the economic importance of these investment vehicles in the US mutual fund industry. Moreover, these funds bore low expense levels $(0.51 \%$ per year $)$ in their portfolios, and had very low turnover ratios (11.87\% annually, approximately). This is coherent with the prevailing passive investment strategy in their portfolio management. 
In addition, Table I shows that the mutual funds under analysis are index funds mainly replicating the S\&P500 stock market index. That is, the number of stocks held in their portfolios (Panel A) was basically the same as those comprising their benchmark. Moreover, the financial results obtained by these funds were slightly lower than the returns of the S\&P500 TR index. For instance, the average annual return of the S\&P500 index funds was $6.14 \%$ during the whole sample period, compared to an average return of $6.59 \%$ for their benchmark (Panel B). The difference between these returns $(0.45 \%)$ was very similar to the overall expenses borne in the funds' portfolios.

Regarding the whole sample period, $2.33 \%$ of the total net assets under average fund management (i.e., 119.89 million dollars) was held as cash or cash equivalents, including currencies, treasury bills, repurchase agreements, and money market funds. Mutual funds usually invest in cash to meet investors' outflows, cover managerial costs and anticipate market downturns (Yan, 2008). These lower risk financial instruments, however, could deteriorate fund performance because their expected returns are lower than the overall stock market index (Wermers, 2000).

Since our goal is to analyze the performance differences of index funds with different liquidity positions in their portfolios, we first sort all the sample funds into five different groups according to their level of cash and cash equivalents. The first group (Quintile 1 or Low) comprises the funds with the lowest levels of cash during a period, while the funds with the highest liquidity positions are included in the last group (Quintile 5 or High). This process is repeated every three months, so these groups are periodically rebalanced. 


\section{(INSERT TABLE II ABOUT HERE)}

Table II presents the annualized return and risk experienced by the average fund in each group. Because of the higher average returns of the benchmark during this period (Panel B of Table I), as expected the group with the highest-cash funds yielded the lowest overall returns in the sample. For instance, these funds obtained an annual return of $6.02 \%$, while the index funds with the lowest cash holdings achieved an average annual return of $6.30 \%$. These differences in fund returns remain regardless of the sub-period considered.

In the following sections, our analyses evaluate the performance of the index funds and aim to comprehend the level of cash holdings in the index fund portfolio, as well as their interactions over the sample period.

\section{Results}

\subsection{Index fund performance}

We start our analyses by assessing the performance of index mutual funds. This is done by estimating the alpha of each fund as in Equation (1). For robustness purposes, we apply this analysis for the entire sample period as well as for the sub-periods considered.

The main results of this analysis are presented in Table III. Specifically, Panel A shows the performance results of S\&P index mutual funds, while Panel B reports the alpha and its significance of the quintile portfolios investing equally-weighted in the group of funds with similar levels of cash positions (from Low to High) during each period. 
Panel A of Table III shows that S\&P500 index mutual funds experience an overall negative alpha of $-0.43 \%$, in annual terms. This alpha is statistically significant at any reasonable level, regardless of the sub-period considered. In addition, the beta and the coefficient of determination are both very close to the unit. This is unsurprising, given the similarity in the behavior of the sample of index funds and their benchmark.

Panel B shows that all the quintile portfolios achieve negative and significant alphas. Nonetheless, funds holding higher levels of cash and cash equivalents in their portfolios experience worse risk-adjusted returns. For example, funds with the highest levels of cash in their portfolios obtained an alpha of $-0.55 \%$ per year during the sample period, which is $0.28 \%$ lower than the annual risk-adjusted returns achieved by low-cash funds, on average. This underperformance of high-cash funds remains when considering any of the sub-periods analyzed.

In addition to considering a pre and post crisis term effect, we also split the sample period into two sub-periods reflecting bullish and bearish S\&P500 periods. It is interesting to analyze whether the relationship between the cash level of the fund and the performance might be driven by an exogenous variable, such as the sign of market return. Therefore, bullish and bearish periods are comprised of those quarters exhibiting only positive and negative S\&P500 returns, respectively. Then, we reapply Equation (1) to assess the corresponding index fund performance. Table IV reports the main results of this analysis. 
Table IV shows that high-cash index funds underperformed their low-cash counterparts during both periods. As reported in the last row of Table IV (High-Low), the differences among the alphas of the quintile portfolios investing in funds with high and low cash positions were negative and statistically significant, ranging between -25 and -48 basis points per year during bull and bear market periods, respectively.

Up to this point, we have observed that the alpha of index funds worsened when we consider greater liquidity positions in their portfolios, regardless of the period considered. This evidence, however, could be explained by other factors driving this cash-performance relationship. Accordingly, in the next sections we analyze the effect of cash holdings on index fund performance while controlling for other characteristics.

\subsection{Controlling for fund expenses}

In this section, we analyze whether the expenses borne in the fund portfolio affect the aforementioned cash-performance relationship. Expensive funds might reasonably be expected to hold higher percentages of liquidity in their portfolios to meet their higher costs. To address this issue, we follow the previous literature (see, for instance, Amihud and Goyenko, 2013; and Vargas et al., 2014) and employ quintile portfolios that invest in each period in funds according to the level of these two variables: cash and expenses.

These portfolios are constructed as follows. Firstly, and for each period, we require all the funds to present data on the two sorting variables. Then, we order all the funds in the sample according to their level of cash and cash equivalents in period $t$, and split the sample into five subsamples in order to consider funds with similar relative levels of liquidity positions in their portfolios. That is, funds with the lowest levels of cash 
comprise the first subsample (Low), while the highest-cash funds are grouped into the fifth subsample (High). Next, we reorder the funds in each subsample according to the level of the second sorting variable (i.e., the net expense ratio borne in each fund), and again split them into five different groups, according to their net expense level (from Low to High). We therefore develop twenty-five quintile portfolios investing equallyweighted in funds with similar levels of two different characteristics. These twenty-five portfolios are periodically rebalanced, so their returns are equal to the average returns of the funds sorted into the corresponding groups during each period.

Table $\mathrm{V}$ reports the performance results for the portfolios investing according to the funds' levels of cash and expenses. Specifically, we apply Equation (1) and present the annualized alpha and significance (t-statistics, in parentheses) of each portfolio during the whole sample period. The alphas of hypothetical portfolios investing in all the funds in each subsample (All) and the performance differences between High and Low portfolios are also presented.

\section{(INSERT TABLE V ABOUT HERE)}

As shown in the All column of Table V, the portfolio investing in index mutual funds that bear high levels of expenses experience worse risk-adjusted returns (an overall alpha of -78 basis points, in annual terms) than low-cost index funds (-8 basis points per year). This difference is statistically significant (t-stat of -11.954).

Regarding low-cost funds, the best performance is achieved by the portfolios investing in low-cash index funds (alpha of $-0.05 \%$, annually), while their high-cash counterparts obtain a significant annualized alpha of $-0.23 \%$. 
Indeed, portfolios investing in funds that maintain greater liquidity positions experienced lower risk-adjusted returns than portfolios investing in their low-cash counterparts. For instance, high-cost funds holding high levels of cash in their portfolios underperform up to $-0.94 \%$ annually, in terms of risk-adjusted returns. Moreover, all the differences in the performance of High- and Low-cash portfolios (last column) are negative. These differences range between 14 and 23 basis points per year, and are statistically significant for most of the expense levels considered. Therefore, the relationship between the level of cash holdings and index fund performance is not driven by the expenses borne by the fund portfolio.

\subsection{Performance of predictive portfolios based on past cash positions}

The above evidence suggests that index funds holding greater cash positions experience lower risk-adjusted returns over time. In this section, we wonder if this underperformance persists over time. It is therefore of interest to develop predictive portfolios in order to forecast the performance of investment strategies based on previous liquidity positions.

Accordingly, we employ a similar methodology to that applied in Table V, but considering previous levels of fund characteristics. For each period we then sort the sample of index funds into five subsamples (from Low to High), according to their cash positions. Also, and given the evidence shown in the literature about mutual fund performance persistence, we split each subsample into five additional groups of index funds (from Low to High), based on their performance. The index funds are thus gathered into twenty-five different groups in each period. 
The next step is to construct several quintile portfolios that invest in funds according to the previous cash position and the previous alpha. That is, the returns of these portfolios during period $t$ are calculated as the overall returns experienced in period $t$ by the funds belonging to the related group in $t-1$. These portfolios are rebalanced until the end of the sample period.

Similarly to Table V, we present the performance and significance of these portfolios in Table VI. The performance results for the portfolios investing in all the funds in each subsample and the performance differences between the High and Low portfolios are also reported.

\section{(INSERT TABLE VI ABOUT HERE)}

As shown in the last row of Table VI, the relative performance of index mutual funds persists over time. In that way, best performing index funds in the past provide investors with performances very close to zero, on average (alpha of -12 basis points per year, $t$ stat of -2.74). Furthermore, the performance of the previous best funds is 64 basis points higher than the performance of the previous worst-performing funds, in annual terms. This performance difference is statistically significant (t-stat of 10.03).

Table VI also shows that the portfolios investing in funds with the highest levels of cash in the past perform worse than their low-cash counterparts. In the same line, we should note that these portfolios perform less well than low-cash portfolios (differences in alphas up to -50 basis points per year). These differences are statistically significant, regardless of the level of previous performance considered. 


\subsection{Explaining cash holdings of index mutual funds}

Up to this point the results show that funds maintaining higher levels of cash holdings in their portfolios experience lower risk-adjusted returns, which has a deteriorating effect on their alphas. This evidence persists over time, even after controlling for different periods, fund expenses and previous fund performance. Nonetheless, other factors that have not yet been considered could also be driving our results. For instance, investors' flows into the funds may increase the liquidity of their portfolios.

For this reason, we now analyze whether cash holdings are affected by several potential factors. To do this we perform time-series regressions for each fund in the sample. This methodology allows the estimates of the regression to vary across funds, so the dependent variable related to each portfolio is allowed to react differently to the explanatory variables. The model is specified as follows:

Cash $_{i, t}=b_{0, i}+b_{1, i}$ NetFlows $_{i, t}+b_{2, i}$ Expenses $_{i, t}+b_{3, i}$ LogTurnover $_{i, t}+b_{4, i}$ LogSize $_{i, t}+b_{5, i}$ $\operatorname{LogAge}_{i, t}+b_{6, i}$ DivEffect $_{t}+b_{7, i} R f_{t}+b_{8, i} \operatorname{VolSP} \operatorname{LoO}_{t}+b_{9, i} \operatorname{Cash}_{i, t-1}+\varepsilon_{i, t}$

where the dependent variable, Cash $_{\mathrm{i}, t}$ is the percentage of cash holdings of the fund $i$ during quarter $t$. The first explanatory variable, NetFlows, is related to investors' flows and is calculated as the percentage of sales minus redemptions that the same fund experiences during the same period t. Expenses is described as the percentage of operating expenses and management fees in relation to the fund assets. LogTurnover, LogSize and LogAge are computed as the natural logarithms of the portfolio turnover reflected in the fund prospectus, the total net assets under the fund management, and the months since the fund inception during the same period, respectively. Additionally, 
the fund's previous level of cash holdings (as a percentage of the previous total net assets) is also included in the regression as $\mathrm{Cash}_{i, t-1}$ in order to test for persistence in the level of cash holdings, which may be related to the funds' liquidity policies.

Other variables external to the fund management are also considered in the model for their potentially significant effects on the funds' liquidity. For instance, DivEffect captures the effect of the dividends; it is estimated as the difference between the return on the S\&P500 TR and the return on the S\&P500 PR indexes in each period, since the latter index does not consider reinvestment of dividends generated. $R f$ is the return on the risk-free asset used in Equation (1) as a proxy of the return yielded by short-term securities. Finally, VolSP500 is associated with market volatility and is described as the standard deviation of the fund benchmark's daily returns during the same period.

To observe the change in the slopes when specific variables are omitted, we apply a series of regression models. The first model only considers the net cash flows, the expenses of each fund and other control variables related to the fund portfolio (turnover, size and age). The second model includes other explanatory variables that are external to the fund management (that is, the dividend effect, the return of the risk-free asset and the volatility of the market). The third model extends the specification of the first one by including the previous cash holdings as an independent variable. Finally, the fourth model considers all the variables considered in Equation (2).

The results of this analysis are displayed in Table VII. We present the mean coefficient for each slope as well as its significance (i.e., the corresponding t-statistic). The adjusted coefficient of determination and the number of funds are also reported. 


\section{(INSERT TABLE VII ABOUT HERE)}

Table VII shows that portfolio liquidity is affected by several fund characteristics. For instance, net flows positively relate to cash holdings in a statistically significant way. This is in line with the idea of funds maintaining part of their holdings as cash to meet investors' needs. Regarding the fund size, the amount of assets under fund management is negatively associated with the fund liquidity, since cash holdings are scaled on the total net assets. Also, an increase in the funds' operating expenses negatively impacts on the cash levels, implying that index funds also hold cash and cash equivalents in their portfolio to meet their operating expenses. Moreover, the coefficient on the previous cash levels is positive and statistically significant (t-stats of 4.42 and 2.17 for models 3 and 4, respectively), denoting a persistence in the level of cash holdings over time. Finally, the overall effect of other external factors on the cash holdings of index mutual funds is not statistically significant at the usual confidence levels.

In light of these results, we next reassess the effect of cash on index fund performance while controlling for other factors that could lead to biased conclusions.

\subsection{Determinants of index fund performance}

Given the results in Table VII, we wonder whether some of the variables affecting index funds' liquidity might be driving the aforementioned cash-performance relationship. To explore this possibility, we now examine how risk-adjusted returns of index funds vary in relation to an increase in the cash holdings while considering other factors in the analysis. 
We address this issue by applying quantile regressions to analyze several levels of fund performance. This method has been applied in previous studies, such as Babalos et al., 2013; Abdelsalam et al., 2014; Moreno and Carrasco, 2015, among others. One of the advantages this methodology has over other regression techniques such as ordinary least squares is that the estimates of the model are more robust against outliers. It also provides a more comprehensive analysis of the effect of the performance determinants by observing different percentiles of the dependent variable.

Accordingly, the risk-adjusted return of index mutual funds in each quarter is considered as the dependent variable of the quantile regression model. Fund riskadjusted returns in each quarter are estimated in considering daily returns in Equation (1). The explanatory variables are the percentage of cash holdings in relation to the total net assets (Cash), investors' net flows (NetFlows), managerial and operating expenses (Expenses), portfolio turnover (LogTurnover), size of the fund (LogSize), fund age since inception $(\log A g e)$, and other variables that could affect fund performance, such as the effect of the dividends (DivEffect) and the market volatility (VolSP500).

Results for several percentiles of index fund performance are presented in Table VIII. Specifically, we present the regression estimates and their t-statistics for five different quantiles (i.e., Q10, Q25, Q50 or median, Q75, and Q90). The pseudo $\mathrm{R}^{2}$ for each regression and the number of fund observations are also reported.

\section{(INSERT TABLE VIII ABOUT HERE)}

As shown in Table VIII, the effect of cash holdings on index fund alphas is negative (and statistically significant for quantiles Q25, Q50 and Q75), even after controlling for other 
factors that could have an impact on both liquidity and fund performance measures. This evidence is in line with the conclusions reached in previous sections. In other words, low-cash index funds provide investors with greater risk-adjusted returns than index funds holding higher levels of cash and cash equivalents in their portfolios.

Table VIII also presents some other interesting results. As expected, the intercept of the model increases to a greater extent when considering higher levels of index fund performance. Moreover, fund performance worsens when considering higher levels of fund expenses, while investors' flows seem to have a non-significant impact on index fund alpha, despite being negative in most of the specified models. The coefficients of other explanatory variables differ, however, in relation to the performance quantile specified. For instance, the age of the fund has a positive and statistically significant effect on index fund performance for the lower quantiles considered, but these estimates are not significant for the regressions related to higher alpha percentiles.

\section{Conclusions}

Index mutual funds are passively-managed portfolios aiming to replicate the behavior of a representative stock market index. With this purpose, these investment vehicles must invest in most of the stocks included in that index, mimicking the benchmark portfolio's structure.

Nonetheless, these funds may also differ from their benchmark by holding short-term securities that provide the liquidity required to meet investors' needs and managerial expenses. These securities are usually described as cash and cash equivalents due to their 
short maturity, and include currencies, treasury bills, repurchase agreements, and money market funds.

It is therefore of interest to assess cash management in these specific funds, since these securities may affect their benchmark-adjusted results. Apart from the expenses borne by the fund portfolio, and given the passive nature of index mutual funds, cash holdings should be one of the few factors determining index fund performance.

Accordingly, this article aimed to evaluate whether higher levels of cash portfolio holdings affect index fund performance. Using a sample of index funds that track the most representative US stock market index (the Standard and Poor's 500 index), we found that funds bearing higher levels of cash holdings in their portfolios experience significantly worse alphas than their low-cash counterparts.

Lower alphas for high-cash funds were found when sub-periods related to different market conditions were considered. Moreover, this underperformance persists over time, and remains even after controlling for managerial and operating costs, investors' flows and other determinants that could affect the cash management or the fund performance.

Hence, this study suggests the inability of index mutual funds to manage their cash efficiently, since higher levels of cash holdings in index funds' portfolios imply a drag on its performance, and provide fund shareholders with lower risk-adjusted returns over time. 


\section{References}

Abdelsalam, O., Fethi, M.D., Matallín, J.C., \& Tortosa-Ausina, E. (2014). On the comparative performance of socially responsible and Islamic mutual funds. Journal of Economic Behavior \& Organization 103, S108-S128.

Adams, J. C., Mansi, S.A., \& Nishikawa, T. (2009). Internal governance mechanisms and operational performance: Evidence from index mutual funds. The Review of Financial Studies 23(3), 1261-1286.

Adams, J.C., Nishikawa, T., \& Rao, R.P. (2016). Mutual fund performance, management teams, and boards. Journal of Banking \& Finance 92, 358-368.

Agapova, A. (2011). Conventional mutual index funds versus exchange-traded funds. Journal of Financial Markets 14(2), 323-343.

Aiello, S., \& Chieffe, N. (1999). International index funds and the investment portfolio. Financial Services Review 8(1), 27-35.

Amihud, Y., \& Goyenko, R. (2013). Mutual fund's $\mathrm{R}^{2}$ as predictor of performance. The Review of Financial Studies 26(3), 667-694.

Babalos, V., Mamatzakis, E., \& Philippas, N. (2013). Estimating performance aspects of Greek equity funds with a liquidity-augmented factor model. Applied Financial Economics 23(8), 629-647.

Baghdadabad, M.R.T., Tanha, F.H. \& Halid, N. (2013). The efficiency evaluation of mutual fund managers based on DARA, CARA, IARA. Journal of Business Economics and Management 14(4): 677-695. 
Berk, J.B., \& Green, R.C. (2004). Mutual fund flows and performance in rational markets. Journal of Political Economy 112(6), 1269-1295.

Bogle, J.C. (2002). An index fund fundamentalist. The Journal of Portfolio Management 28(3), 31-38.

Bogle, J.C. (2016). The index mutual fund: 40 years of growth, change, and challenge. Financial Analysts Journal 72(1), 9-13.

Chang, C.E., \& Krueger, T. (2010). Do enhanced index funds live up to their name?. Financial Services Review 19(2), 145-162.

Chen, H., Noronha, G., \& Singal, V. (2006). Index changes and losses to index fund investors. Financial Analysts Journal 62(4), 31-47.

Elebash, C.C. (1993). Public pensions: Big investors in stock index funds. Benefits Quarterly 9(1), 86-93.

Elton, E.J., Gruber, M.J., Comer, G., \& Li, K. (2002). Spiders: Where are the bugs? The Journal of Business 75(3), 453-472.

Evans, R.B. (2010). Mutual fund incubation. The Journal of Finance 65(4), 1581-1611.

Frino, A., \& Gallagher, D.R. (2001). Tracking S\&P 500 index funds. The Journal of Portfolio Management 28(1), 44-55.

Frino, A., \& Gallagher, D.R. (2002). Is index performance achievable? An analysis of Australian equity index funds. Abacus 38(2), 200-214.

Green, T.C. \& Jame, R. (2011). Strategic trading by index funds and liquidity provision around S\&P 500 index additions. Journal of Financial Markets 14(4), 605-624. 
Gruber, M.J. (1996). Another puzzle: The growth in actively managed mutual funds. The Journal of Finance 51(3), 783-810.

Jensen, M.C. (1968). The performance of mutual funds in the period 1945-1964. The Journal of Finance 23(2), 389-416.

Kostovetsky, L. (2003). Index Mutual Funds and Exchange-Traded Funds. The Journal of Portfolio Management 29(4), 80-92.

Malkiel, B.G. (2003). Passive investment strategies and efficient markets. European Financial Management 9(1), 1-10.

Moreno, J.D.J., \& Carrasco, O.R. (2015). Evolution of efficiency and its determinants in the retail sector in Spain: new evidence. Journal of Business Economics and Management 16(1), 244-260.

Newey, W.K., \& West, K.D. (1987). A simple, positive semi-definite, heteroskedasticity and autocorrelation consistent covariance matrix. Econometrica 55(3), 703-708.

Opler, T., Pinkowitz, L., Stulz, R., \& Williamson, R. (1999). The determinants and implications of corporate cash holdings. Journal of Financial Economics 52(1), 3-46.

Petajisto, A. (2011). The index premium and its hidden cost for index funds. Journal of Empirical Finance 18(2), 271-288.

Simutin, M. (2010). Excess cash and stock returns. Financial Management 39(3), 1197-1222. Simutin, M. (2014). Cash holdings and mutual fund performance. Review of Finance 18(4), $1425-1464$. 
Strydom, B., Charteris, A., \& McCullough, K. (2015). The relative tracking ability of South African exchange traded funds and index funds. Investment Analysts Journal 44(2), 117-133.

Vargas, M., Vicente, R., \& Muñoz, F. (2014). Searching for the most profitable and sustainable investment strategy: Evidence from sovereign bond funds. Journal of Business Economics and Management 15(5), 1034-1053.

Wermers, R. (2000). Mutual fund performance: An empirical decomposition into stock-picking talent, style, transactions costs, and expenses. The Journal of Finance 55(4), 1655-1695.

Yan, X. (2006). The determinants and implications of mutual fund cash holdings: Theory and evidence. Financial Management 35(2), 67-91.

Yan, X.S. (2008). Liquidity, investment style, and the relation between fund size and fund performance. Journal of Financial and Quantitative Analysis 43(3), 741-767. 


\begin{tabular}{|c|c|c|c|c|c|c|}
\hline \multicolumn{7}{|l|}{ Panel A. Index fund characteristics } \\
\hline & \multicolumn{2}{|c|}{ Jan 1999-Dec 2016} & \multicolumn{2}{|c|}{ Jan 1999-Dec 2007} & \multicolumn{2}{|c|}{ Jan 2008-Dec 2016} \\
\hline & Mean & S.D. & Mean & S.D. & Mean & S.D. \\
\hline TNA (millions) & $5,138.718$ & $17,759.021$ & $3,640.921$ & $13,411.866$ & $6,582.454$ & $22,838.449$ \\
\hline Annualized net return (\%) & 6.142 & 16.048 & 4.327 & 15.155 & 7.958 & 16.845 \\
\hline Cash and cash equivalents (\%) & 2.333 & 5.077 & 2.346 & 3.715 & 2.319 & 6.200 \\
\hline Turnover $(\%)$ & 11.868 & 24.709 & 12.503 & 19.633 & 11.183 & 29.200 \\
\hline Net Expense Ratio (\%) & 0.506 & 0.319 & 0.514 & 0.317 & 0.496 & 0.320 \\
\hline Number of stocks & 499.499 & 7.884 & 498.866 & 8.717 & 500.146 & 6.871 \\
\hline Number of funds & 104 & & 102 & & 72 & \\
\hline \multicolumn{7}{|l|}{ Panel B. Benchmark characteristics } \\
\hline & \multicolumn{2}{|c|}{ Jan 1999-Dec 2016} & \multicolumn{2}{|c|}{ Jan 1999-Dec 2007} & \multicolumn{2}{|c|}{ Jan 2008-Dec 2016} \\
\hline & Mean & S.D. & Mean & S.D. & Mean & S.D. \\
\hline Risk-free asset annualized return (\%) & 1.795 & 1.008 & 3.358 & 0.859 & 0.232 & 0.266 \\
\hline S\&P500 annualized return (\%) & 6.589 & 16.097 & 4.784 & 15.216 & 8.395 & 16.884 \\
\hline Number of stocks included in S\&P500 & 499.843 & 6.692 & 498.713 & 9.165 & 500.972 & 1.734 \\
\hline
\end{tabular}

This table presents the mean and standard deviation for several characteristics of the index fund sample (Panel A), including the number of funds in the sample, the total net assets under fund management (TNA), their annualized net return, turnover ratio, net expense ratio, and number of different stocks held in the fund portfolio. Panel B reports the same descriptive statistics for the annualized return of the risk-free asset (one-month Treasury Bill rate), the annualized return of the index fund benchmark (Standard and Poor's 500 Total Return index), and the number of different stocks in the benchmark portfolio. 
Table II. Annualized portfolio return and risk, quintiles sorted on cash positions

\begin{tabular}{|c|c|c|c|c|c|c|}
\hline & \multicolumn{2}{|c|}{ Jan 1999-Dec 2016} & \multicolumn{2}{|c|}{ Jan 1999-Dec 2007} & \multicolumn{2}{|c|}{ Jan 2008-Dec 2016} \\
\hline & Return (\%) & S.D. (\%) & Return (\%) & S.D. $(\%)$ & Return (\%) & S.D. $(\%)$ \\
\hline Quintile 1 (low) & 6.299 & 16.040 & 4.547 & 15.117 & 8.051 & 16.868 \\
\hline Quintile 2 & 6.151 & 16.062 & 4.310 & 15.183 & 7.991 & 16.845 \\
\hline Quintile 3 & 6.099 & 16.064 & 4.255 & 15.175 & 7.943 & 16.856 \\
\hline Quintile 4 & 6.135 & 16.056 & 4.317 & 15.174 & 7.952 & 16.844 \\
\hline Quintile 5 (high) & 6.016 & 16.019 & 4.190 & 15.128 & 7.843 & 16.813 \\
\hline
\end{tabular}

This table presents the annualized net return and risk of index mutual funds with different levels of cash holdings. Specifically, for each period funds are sorted into quintiles, according to the level of cash portfolio holdings. Quintile 1 (low) refers to the group of funds with the lowest level of cash holdings, while Quintile 5 (high) includes the group of funds with the highest cash portfolio positions. 


\section{Table III. Performance of S\&P500 index mutual funds}

Panel A. Overall results for index mutual funds

\begin{tabular}{|c|c|c|c|c|c|c|}
\hline & \multicolumn{2}{|c|}{ Jan 1999-Dec 2016} & \multicolumn{2}{|c|}{ Jan 1999-Dec 2007} & \multicolumn{2}{|c|}{ Jan 2008-Dec 2016} \\
\hline & Mean & P-value & Mean & P-value & Mean & P-value \\
\hline alpha (annualized) & $-0.0043^{* * *}$ & $(0.0000)$ & $-0.0045^{* * *}$ & $(0.0000)$ & $-0.0042^{* * *}$ & $(0.0000)$ \\
\hline Beta & $0.9969^{* * *}$ & $(0.0000)$ & $0.9959^{* * *}$ & $(0.0000)$ & $0.9977^{* * *}$ & $(0.0000)$ \\
\hline $\mathrm{R}^{2}$ & 0.999998 & & 0.999980 & & 0.999992 & \\
\hline
\end{tabular}

Panel B. Annualized alpha of quintile portfolios, sorted on cash position

\begin{tabular}{|c|c|c|c|c|c|c|}
\hline & \multicolumn{2}{|c|}{ Jan 1999-Dec 2016} & \multicolumn{2}{|c|}{ Jan 1999-Dec 2007} & \multicolumn{2}{|c|}{ Jan 2008-Dec 2016} \\
\hline & Mean & P-value & Mean & P-value & Mean & P-value \\
\hline Q1 (Low) & $-0.0027^{* * *}$ & $(0.0000)$ & $-0.0023^{* *}$ & $(0.0194)$ & $-0.0034^{* * *}$ & $(0.0000)$ \\
\hline Q2 & $-0.0043^{* * *}$ & $(0.0000)$ & $-0.0047^{* * *}$ & $(0.0000)$ & $-0.0038^{* * *}$ & $(0.0000)$ \\
\hline Q3 & $-0.0048^{* * *}$ & $(0.0000)$ & $-0.0053^{* * *}$ & $(0.0000)$ & $-0.0044^{* * *}$ & $(0.0000)$ \\
\hline Q4 & $-0.0044^{* * *}$ & $(0.0000)$ & $-0.0046^{* * *}$ & $(0.0000)$ & $-0.0042^{* * *}$ & $(0.0000)$ \\
\hline Q5 (High) & $-0.0055^{* * *}$ & $(0.0000)$ & $-0.0059^{* * *}$ & $(0.0000)$ & $-0.0052^{* * *}$ & $(0.0000)$ \\
\hline High-Low & $-0.0028^{* * *}$ & $(0.0000)$ & $-0.0036^{* * *}$ & $(0.0000)$ & $-0.0018^{* *}$ & $(0.0192)$ \\
\hline
\end{tabular}

This table presents the main results for the performance of index funds, measured by Equation (1). Results are reported for the whole sample period and for two sub-periods. Panel A shows the annualized alpha and the funds' beta in relation to their benchmark for all the funds in the sample, as well as their coefficient of determination. Panel B reports the annualized alpha of quintile-portfolios that invest in index funds according to their cash position. The difference and significance between the High and the Low quintile-portfolios are also reported. P-values (in parentheses) are from Newey-West's (1987) heteroscedasticity and autocorrelation consistent covariance estimator; ${ }^{* *}$ and ${ }^{* * *}$ denote significance at $5 \%$ and $1 \%$ levels, respectively. 
Table IV. Performance of S\&P500 index mutual funds during bullish and bearish periods

Panel A. Overall results for index mutual funds

\begin{tabular}{lccccc}
\hline & \multicolumn{2}{c}{ Bullish periods $\left(R_{S \& P 500}>0\right)$} & & \multicolumn{2}{c}{ Bearish periods $\left(R_{S \& P 500}<0\right)$} \\
\cline { 2 - 3 } alpha (annualized) & Mean & P-value & & Mean & P-value \\
\cline { 2 - 3 } Beta & $-0.0049^{* * *}$ & $(0.0000)$ & & $-0.0038^{* * *}$ & $(0.0000)$ \\
$R^{2}$ & $0.9989^{* * *}$ & $(0.0000)$ & & $0.9976^{* * *}$ & $(0.0000)$ \\
\hline
\end{tabular}

Panel B. Annualized alpha of quintile portfolios, sorted on cash position

\begin{tabular}{lcccccc}
\hline & \multicolumn{2}{c}{ Bullish periods $\left(\mathrm{R}_{\text {S\&P500 }}>0\right)$} & & \multicolumn{2}{c}{ Bearish periods $\left(\mathrm{R}_{\text {S\&P500 }}<0\right)$} \\
\cline { 2 - 3 } \cline { 5 - 6 } \cline { 5 - 6 } Q1 (Low) & Mean & P-value & & Mean & P-value \\
\hline Q2 & $-0.0040^{* * *}$ & $(0.0000)$ & & -0.0010 & $(0.6691)$ \\
Q3 & $-0.0044^{* * *}$ & $(0.0000)$ & & $-0.0050^{* * *}$ & $(0.0000)$ \\
Q4 & $-0.0052^{* * *}$ & $(0.0000)$ & & $-0.0027^{* * *}$ & $(0.0014)$ \\
Q5 (High) & $-0.0046^{* * *}$ & $(0.0000)$ & & $-0.0045^{* * *}$ & $(0.0000)$ \\
High-Low & $-0.0065^{* * *}$ & $(0.0000)$ & & $-0.0058^{* * *}$ & $(0.0000)$ \\
\cline { 1 - 2 } & $-0.0025^{* * *}$ & $(0.0001)$ & & $-0.0048^{* *}$ & $(0.0347)$ \\
\hline
\end{tabular}

This table presents the performance results for index funds during bearish and bullish periods. Index fund performance is measured by Equation (1). Panel A shows the annualized alpha and the funds' beta in relation to their benchmark for all the funds in the sample, as well as their coefficient of determination. Panel B reports the annualized alpha of quintile-portfolios that invest in index funds according to their cash position. The difference and significance between the High and the Low quintile-portfolios are also reported. P-values (in parentheses) are from Newey-West's (1987) heteroscedasticity and autocorrelation consistent covariance estimator; ${ }^{* *}$ and ${ }^{* * *}$ denote significance at $5 \%$ and $1 \%$ levels, respectively. 
Table V. Portfolio alphas, sorted on different levels of cash and expenses

\begin{tabular}{rcccccccc}
\hline & & \multicolumn{7}{c}{ Cash } \\
\hline Expenses & & Low & Q2 & Q3 & Q4 & High & All & High-Low \\
\hline Low & Alpha & $-0.0005^{* * * *}$ & $-0.0007^{* * *}$ & $-0.0014^{* * *}$ & $-0.0013^{* *}$ & $-0.0023^{* * *}$ & $-0.0008^{* * *}$ & $-0.0018^{* * *}$ \\
& t-stat & $(-5.124)$ & $(-2.826)$ & $(-6.162)$ & $(-2.490)$ & $(-8.076)$ & $(-5.492)$ & $(-6.065)$ \\
Q2 & Alpha & $-0.0021^{* * *}$ & $-0.0025^{* * *}$ & $-0.0038^{* * *}$ & $-0.0036^{* * *}$ & $-0.0040^{* * *}$ & $-0.0029^{* * *}$ & $-0.0019^{* * *}$ \\
& t-stat & $(-6.588)$ & $(-5.569)$ & $(-10.746)$ & $(-18.985)$ & $(-15.878)$ & $(-16.462)$ & $(-4.734)$ \\
Q3 & Alpha & $-0.0035^{* * *}$ & $-0.0044^{* * *}$ & $-0.0053^{* * *}$ & $-0.0046^{* * *}$ & $-0.0058^{* * *}$ & $-0.0048^{* * *}$ & $-0.0023^{* * *}$ \\
& t-stat & $(-16.969)$ & $(-16.525)$ & $(-28.065)$ & $(-10.300)$ & $(-15.801)$ & $(-36.557)$ & $(-4.910)$ \\
Q4 & Alpha & $-0.0043^{* * *}$ & $-0.0060^{* * *}$ & $-0.0067^{* * *}$ & $-0.0064^{* * *}$ & $-0.0057^{* * *}$ & $-0.0061^{* * *}$ & -0.0014 \\
& t-stat & $(-4.907)$ & $(-15.289)$ & $(-7.578)$ & $(-23.744)$ & $(-10.304)$ & $(-23.407)$ & $(-1.296)$ \\
High & Alpha & $-0.0071^{* * *}$ & $-0.0073^{* * *}$ & $-0.0071^{* * *}$ & $-0.0067^{* * *}$ & $-0.0094^{* * *}$ & $-0.0078^{* * *}$ & -0.0023 \\
& t-stat & $(-11.126)$ & $(-28.001)$ & $(-12.757)$ & $(-9.847)$ & $(-4.661)$ & $(-12.997)$ & $(-1.106)$ \\
All & Alpha & $-0.0034^{* * * *}$ & $-0.0041^{* * *}$ & $-0.0048^{* * *}$ & $-0.0044^{* * *}$ & $-0.0057^{* * *}$ & $-0.0045^{* * *}$ & $-0.0023^{* * *}$ \\
& t-stat & $(-23.145)$ & $(-18.821)$ & $(-16.914)$ & $(-21.048)$ & $(-11.760)$ & $(-25.185)$ & $(-4.743)$ \\
High-Low & Alpha & $-0.0066^{* * *}$ & $-0.0066^{* * *}$ & $-0.0057^{* * *}$ & $-0.0054^{* * *}$ & $-0.0071^{* * *}$ & $-0.0070^{* * *}$ &
\end{tabular}

This Table presents the annualized alpha of quintile-portfolios that invest in index funds with similar characteristics in each period. Specifically, these portfolios are based on a double sorting procedure related to levels of cash holdings and expenses. The performance differences between High and Low portfolios are also reported. T-statistics (in parentheses) are from Newey-West's (1987) heteroscedasticity and autocorrelation consistent covariance estimator; ${ }^{* *}$ and ${ }^{* * *}$ denote significance at $5 \%$ and $1 \%$ levels, respectively. 
Table VI. Portfolio alphas, sorted on previous cash positions and previous alpha

\begin{tabular}{|c|c|c|c|c|c|c|c|c|}
\hline 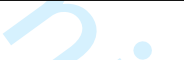 & \multicolumn{8}{|c|}{ Previous cash position } \\
\hline Past Alpha & & Low & Q2 & Q3 & Q4 & High & All & High-Low \\
\hline Low & Alpha & $-0.0066^{* * *}$ & $-0.0076^{* * *}$ & $-0.0066^{* * *}$ & $-0.0056^{* * *}$ & $-0.0097^{* * *}$ & $-0.0076^{* * *}$ & $-0.0031^{* * *}$ \\
\hline & t-stat & $(-20.808)$ & $(-10.815)$ & $(-14.464)$ & $(-3.516)$ & $(-11.041)$ & $(-17.244)$ & $(-3.108)$ \\
\hline \multirow[t]{2}{*}{ Q2 } & Alpha & $-0.0048^{* * *}$ & $-0.0063^{* * *}$ & $-0.0058^{* * *}$ & $-0.0055^{* * *}$ & $-0.0056^{* * *}$ & $-0.0059^{* * *}$ & $-0.0008^{* *}$ \\
\hline & t-stat & $(-11.561)$ & $(-20.507)$ & $(-18.409)$ & $(-24.090)$ & $(-16.796)$ & $(-30.535)$ & $(-2.039)$ \\
\hline \multirow[t]{2}{*}{ Q3 } & Alpha & $-0.0028^{* * *}$ & $-0.0042^{* * *}$ & $-0.0048^{* * *}$ & $-0.0043^{* * *}$ & $-0.0050^{* * *}$ & $-0.0042^{* * *}$ & $-0.0022^{* * *}$ \\
\hline & t-stat & $(-9.123)$ & $(-14.424)$ & $(-17.413)$ & $(-13.796)$ & $(-12.822)$ & $(-20.342)$ & $(-5.741)$ \\
\hline \multirow[t]{2}{*}{ Q4 } & Alpha & $-0.0021^{* * *}$ & $-0.0028^{* * *}$ & $-0.0030^{* * *}$ & $-0.0035^{* * *}$ & $-0.0031^{* * *}$ & $-0.0030^{* * *}$ & $-0.0011^{*}$ \\
\hline & t-stat & $(-6.958)$ & $(-8.763)$ & $(-5.448)$ & $(-12.267)$ & $(-5.289)$ & $(-18.504)$ & $(-1.766)$ \\
\hline \multirow[t]{2}{*}{ High } & Alpha & 0.0006 & $-0.0012^{* * *}$ & $-0.0019^{* * *}$ & $-0.0027^{* * *}$ & $-0.0044^{* * *}$ & $-0.0012^{* * *}$ & $-0.0050^{* * *}$ \\
\hline & t-stat & $(0.515)$ & $(-4.403)$ & $(-4.397)$ & $(-4.459)$ & $(-3.972)$ & $(-2.736)$ & $(-4.244)$ \\
\hline \multirow[t]{2}{*}{ All } & Alpha & $-0.0032^{* * *}$ & $-0.0044^{* * *}$ & $-0.0044^{* * *}$ & $-0.0044^{* * *}$ & $-0.0057^{* * *}$ & $-0.0044^{* * *}$ & $-0.0025^{* * *}$ \\
\hline & t-stat & $(-8.268)$ & $(-23.149)$ & $(-20.470)$ & $(-10.401)$ & $(-15.584)$ & $(-25.455)$ & $(-6.518)$ \\
\hline \multirow[t]{2}{*}{ High-Low } & Alpha & $0.0071^{* * *}$ & $0.0064^{* * *}$ & $0.0047^{* * *}$ & $0.0029^{*}$ & $0.0053^{* * *}$ & $0.0064^{* * *}$ & \\
\hline & t-stat & $(6.666)$ & $(8.348)$ & $(8.476)$ & $(1.884)$ & $(4.485)$ & $(10.032)$ & \\
\hline
\end{tabular}

This Table presents the annualized alpha of quintile-portfolios that in each period invest in index funds with similar characteristics. Specifically, these portfolios are based on a double sorting procedure related to the previous level of cash holdings and previous alpha. The performance differences between High and Low portfolios are also reported. T-statistics (in parentheses) are from Newey-West's (1987) heteroscedasticity and autocorrelation consistent covariance estimator; ${ }^{* *}$ and ${ }^{* * *}$ denote significance at $5 \%$ and $1 \%$ levels, respectively. 
Table VII. Determinants of index fund cash management

\begin{tabular}{|c|c|c|c|c|c|c|c|c|}
\hline( & \multicolumn{2}{|c|}{ Regression 1} & \multicolumn{2}{|c|}{ Regression 2} & \multicolumn{2}{|c|}{ Regression 3} & \multicolumn{2}{|c|}{ Regression 4} \\
\hline & Mean & T-stat & Mean & T-stat & Mean & T-stat & Mean & T-stat \\
\hline Constant & $20.5287^{* * *}$ & (3.068) & $19.3762^{* *}$ & (2.019) & $16.5685^{* *}$ & (2.549) & $19.7848^{*}$ & (1.680) \\
\hline NetFlows & $0.0399^{* *}$ & (2.539) & $0.0310^{* *}$ & $(2.130)$ & $0.0401^{* *}$ & (2.492) & $0.0322^{* *}$ & (2.070) \\
\hline Expenses & -5.3182 & $(-1.580)$ & $-6.9101^{* *}$ & $(-2.192)$ & -4.4635 & $(-1.305)$ & $-6.1587^{*}$ & $(-1.725)$ \\
\hline LogTurnover & -0.0697 & $(-0.461)$ & -0.1589 & $(-0.757)$ & -0.0871 & $(-0.573)$ & -0.2544 & $(-1.109)$ \\
\hline LogSize & $-0.5655^{* *}$ & $(-2.192)$ & -0.4602 & $(-1.263)$ & $-0.4958^{*}$ & $(-1.951)$ & -0.6269 & $(-1.501)$ \\
\hline LogAge & $-1.4089^{* * *}$ & $(-2.591)$ & -0.9001 & $(-1.156)$ & $-1.1156^{* *}$ & $(-2.321)$ & -0.6345 & $(-0.693)$ \\
\hline DivEffect & & & -0.8523 & $(-0.658)$ & & & -0.1441 & $(-0.126)$ \\
\hline VolSP500 & & & 0.0159 & (1.163) & & & 0.0142 & $(0.987)$ \\
\hline $\mathrm{Rf}$ & & & 0.2860 & $(0.412)$ & & & 0.3067 & $(0.485)$ \\
\hline LagCash & & & & & $0.1354^{* * *}$ & $(4.424)$ & $0.0682^{* *}$ & $(2.171)$ \\
\hline Adj. $R^{2}$ & 0.2302 & & 0.2744 & & 0.2725 & & 0.3007 & \\
\hline Number of funds & 43 & & 43 & & 41 & & 41 & \\
\hline
\end{tabular}

This Table presents the main results of time-series regressions for each index fund in the sample. The dependent variable is the cash portfolio holdings in each period. The independent variables include investors' flows (NetFlows), net expense ratio (Expenses), natural logarithm of turnover ratio (LogTurnover), natural logarithm of total net assets (LogSize), natural logarithm of months since inception $(\log A g e)$, effect of the dividends reinvested in the benchmark (DivEffect), benchmark volatility (VolSP500), the return of the risk-free asset (Rf), and the previous level of cash holdings in the index fund portfolio (LagCash). T-statistics (in parentheses) are from Newey-West's (1987) heteroscedasticity and autocorrelation consistent covariance estimator; ${ }^{*},{ }^{* *}$ and ${ }^{* * *}$ denote significance at $10 \%, 5 \%$, and $1 \%$ levels, respectively. The adjusted coefficient of determinations and the number of funds included in the analyses are also reported. 


\section{Table VIII. Determinants of index fund performance}

\begin{tabular}{|c|c|c|c|c|c|c|c|c|c|c|}
\hline & Q & & Q & & Q & & & & & \\
\hline & Coef. & T-stat & Coef. & T-stat & Coef. & T-stat & Coef. & T-stat & Coef. & T-stat \\
\hline Constant & $-0.9628^{* * *}$ & $(-5.160)$ & $-0.4199^{* * *}$ & $(-5.380)$ & -0.0821 & $(-1.310)$ & $0.3255^{* * *}$ & $(3.420)$ & $0.9254^{* * *}$ & $(3.790)$ \\
\hline Cash & -0.0118 & $(-1.290)$ & $-0.0104^{* * *}$ & $(-4.150)$ & $-0.0069^{* * *}$ & $(-2.870)$ & $-0.0052^{* * *}$ & $(-2.670)$ & -0.0076 & $(-1.070)$ \\
\hline NetFlows & -0.0016 & $(-1.060)$ & -0.0007 & $(-1.120)$ & -0.0002 & $(-0.290)$ & 0.0003 & $(0.330)$ & -0.0010 & $(-0.570)$ \\
\hline Expenses & $-0.9286^{* * *}$ & $(-21.160)$ & $-0.9649^{* * *}$ & $(-48.840)$ & $-0.9659^{* * *}$ & $(-62.430)$ & $-0.9259^{* * *}$ & $(-30.750)$ & $-0.9053^{* * *}$ & $(-13.220)$ \\
\hline LogTurnover & $-0.0309^{*}$ & $(-1.950)$ & -0.0006 & $(-0.080)$ & 0.0066 & $(0.970)$ & $0.0177^{*}$ & $(1.740)$ & $0.0442^{* *}$ & $(2.130)$ \\
\hline LogSize & $0.0264^{* * *}$ & $(4.070)$ & $0.0088^{* * *}$ & $(2.980)$ & -0.0033 & $(-1.390)$ & $-0.0182^{* * *}$ & $(-4.540)$ & $-0.0445^{* * *}$ & $(-5.280)$ \\
\hline LogAge & $0.0469^{* * *}$ & $(2.790)$ & $0.0329^{* * *}$ & (3.320) & 0.0127 & $(1.360)$ & -0.0095 & $(-0.770)$ & -0.0046 & $(-0.180)$ \\
\hline DivEffect & 0.0541 & $(1.390)$ & 0.0210 & $(1.160)$ & $0.0384^{* * *}$ & $(3.240)$ & $0.0634^{* * *}$ & $(3.130)$ & 0.0427 & (1.140) \\
\hline VolSP500 & $-0.0042^{* *}$ & $(-2.480)$ & $-0.0014^{* *}$ & $(-2.000)$ & $0.0021^{* * *}$ & $(3.610)$ & $0.0046^{* * *}$ & $(4.400)$ & $0.0106^{* * *}$ & $(5.220)$ \\
\hline Pseudo $R^{2}$ & 0.285 & & 0.3291 & & 0.3202 & & 0.2322 & & 0.0987 & \\
\hline Number of observations & 2,178 & & 2,178 & & 2,178 & & 2,178 & & 2,178 & \\
\hline
\end{tabular}

This table presents the main results for applying quantile regression to the index funds in the sample. The dependent variable is the index fund performance, measured as the annualized alpha. The explanatory variables include the level of cash holdings (Cash), investors' flows (NetFlows), net expense ratio (Expenses), natural logarithm of turnover ratio (LogTurnover), natural logarithm of total net assets (LogSize), natural logarithm of months since inception (LogAge), effect of the dividends reinvested in the benchmark (DivEffect), and benchmark volatility (VolSP500). Five different quantiles of the conditional performance distribution are considered, namely Q10, Q25, Q50 (i.e., the median), Q75, and Q90. Quantile regression results are based on 10,000 bootstrapping repetitions. T-statistics are reported in parentheses, and ${ }^{*} * *$ and ${ }^{* * *}$ denote significance at $10 \%, 5 \%$, and $1 \%$ levels, respectively. 